\title{
羊毛の吸湿挙動に及ぼすサクシニル化の影響
}

\author{
昭和女子大学大学院 生活機構研究科 小原奈津子*1 ・ 中島利誠 \\ 日本繊維製品卸検查協会 山口奈穂子*2
}

\section{The Influence of Succinylation on Moisture Sorption of Wool Fibers}

\author{
Natsuko Kohara $^{* 1}$, Toshinari Nakajima, and Naoko Yamaguchi ${ }^{* 2}$ \\ ${ }^{* 1}$ Graduate School of Human Life Sciences, Showa Women's University, 1-7, Taishido, Setagayaku, \\ Tokyo 154-8533, Japan \\ *2 Japan Textile Products Wholesalers Inspecting Foundation, 8-10, Nihonbashi Tomizawacho, Chuoku, \\ Tokyo 103-0006, Japan
}

\begin{abstract}
Sorption isotherms of reduced and succinylated wool and then desalted completely or partially were obtained and the moisture sorption behaviors on these treated wools were compared with those on reduced and intact wools in order to clarify the influence of succinylation on the moisture sorption. $\mathrm{COO}^{-} \mathrm{M}^{+}$group introduced into wool keratin by succinylation is more effective to improve the moisture sorpability than decrease of the crystallinity. $\mathrm{OH}$ and $\mathrm{NH}_{2}$ groups which are reaction sites in succinylation, contribute to the moisture sorption slightly more than $\mathrm{COOH}$ group. The sorption behaviors on these treated wools were explained by BET multilayer sorption theory combined with polymer solution theory.
\end{abstract}

(Received ; 7 November, 2006 ; Accepted 22 January, 2007)

\section{1. 緒 言}

これまで䋊維化学分野において吸湿性付与を目的とし た種々の工夫が，衣料のみならず産業資材や住居材料へ の用途に向けてなされてきた。一般に, 高分子の吸湿性 には化学構造, 結晶化度, 非晶領域中の極性基の分布な どが関係するといわれている，我々は，羊毛繊維の反応 特性を生かした化学修飾により, 廃羊毛を衣料用以外の 用途にも利用可能な新規の機能性材料に変換することを 最終目的としていくつかの試みを行ってきた[1-3]. 先の 研究では酸化, 還元あるいは部分加水分解などの簡易な 前処理とサクシニル化の組み合わせにより, 羊毛の吸水 性と吸湿性が著しく向上することを見出した [3]. サクシ ニル化反応では, 図 1 の反応例に示すように無水コハク 酸は弱いアルカリ条件下でアミノ酸側鎖のアミノ基，水 酸基あるいはチオール基のような活性水素を有する官能

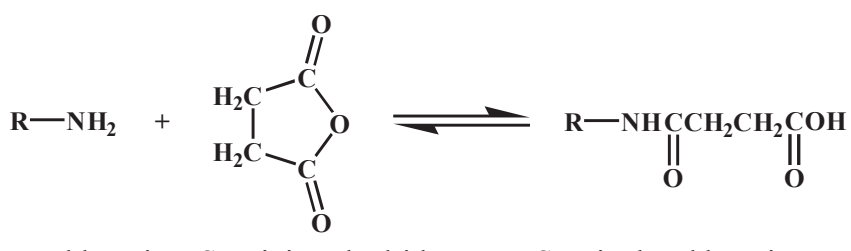

Wool keratin Succinic anhydride

Succinylated keratin

Fig. 1 Succinylation of wool keratin
基に付加する $[4]$.この反応では 1 モルの無水コハク酸が 付加すると 1 当量のカルボキシル基が導入されることに なる. 前報では, サクシニル化反応は非晶領域から結晶 領域に進行し, 無水コハク酸の付加率の増加とともに羊 毛の結晶化度が低下すること, 還元後サクシニル化した 羊毛の $85 \%$ R.H. での水分率は無水コハク酸の付加率の増 加および結晶化度の低下に対して直線的に増加すること を報告した $[5]$.

化学処理による高分子の機能化や改質では, 意図する 化学構造の変化だけでなくしばしば高次構造の変化をも 伴う. 処理による化学構造の変化と副次的に起こる高次 構造の変化が，それぞれ高分子材料の特性の変化に実質 的にはどれほど関与しているのかはこれまであまり議論 されてこなかったが，化学改質の開発においては重要な 意義をもつ. 本研究では還元後サクシニル化した羊毛を 対象に, この化学処理によって起こる化学構造の変化と これに伴う結晶化度の低下が羊毛の吸湿挙動にどのよう な影響をもたらしているかを検討した。

\section{2. 実 験}

\section{1 試料}

ニュージーランド産コリデール種羊毛をベンゼン・エ タノール $(1: 1)$ 混合溶液に室温で 24 時間浸漬した後, ジ 
エチルエーテルで 10 時間ソックスレー抽出した $[6]$.

\section{2 化学処理}

還元：上記のように精製した羊毛繊維を $40^{\circ} \mathrm{C}$ の $3 \mathrm{M} \mathrm{2-}$ メルカプトエタノール水溶液中 (浴比 $1: 100)$ で 6 時間振 とう後, 水で繰り返し洗浄した $[3]$.

サクシニル化: 還元した羊毛繊維を $\mathrm{pH} 8.0$ の 1/15M リ ン酸緩衝溶液中 (浴比 $1: 50)$ に浸漬し, 無水コハク酸 $(6.85 \mathrm{~g} / \mathrm{g} \cdot$ wool $)$ を少量ずつ加えた後, 室温で 24 時間かく はんした。この間, 溶液の $\mathrm{pH}$ を 8.0 に保つために, $10 \mathrm{M}$ $\mathrm{NaOH}$ 水溶液を適宜加えた. 反応終了後, 水で繰り返し 洗浄した [3].

脱塩処理 : 還元後サクシニル化した試料を透析用セル ロースチューブ(US-32-100, 三光純薬(株))に移し，電解透 析用コンスタパワーを接続した電解透析器を用いて, イ オン交換水中で $100 \mathrm{~V}$ の電圧をかけて電流が低下しなくな るまで(最終時の電流: $2.6 \mathrm{~mA})$, 透析を続けた。一部の試 料は電流が $6 \mathrm{~mA}$ になった時点で透析を終了し, 部分的に 脱塩された試料として用いた。

\section{3 分析および測定}

付加率: サクシニル化還元羊毛を $6 \mathrm{M}$ 塩酸中 (浴比 1 : 1000), $110^{\circ} \mathrm{C}$ で 48 時間加水分解し, ロータリーエバポレー ターを用いて減圧下で塩酸を除去した。得られた加水分 解物を再び水溶液にし, マキシクリーン (IC-H, 信和加工 (株)を通してアミノ酸を除去した後, 内部基準物質として 酢酸を加え, 試料中のコハク酸量を液体クロマトグラフ 分析機 (CTO-6A, SPD-6A, 島津製作所(株) で定量した.

チオール基量 : Du Toit らの方法[7]に従って, 約 30mg の還元羊毛を $15 \%$ 硫酸 (浴比 $1: 100$ ) で加水分解後, 5,5'ジチオビス (2-ニトロ安息香酸)を用いて分光光度法で定 量した.

$\mathrm{Na}, \mathrm{K}$ 含有量 : 硝酸 $(20 \mathrm{~mL})$ /過塩素酸 $(5 \mathrm{~mL})$ 混合溶液中 で加熱分解した試料 $(70 \sim 400 \mathrm{mg}$ ) 溶液の容積を純水で 20 $\mathrm{mL}$ にし高周波プラズマ発光分析装置 (ICPS-7500, 島津製 作所(株) で定量した。

結晶化度: 前報 $[5]$ と同様に自動 X 線回折装置(RINT 2000/PC, (株リガク)を用いて平行ビーム光学系を使用し て $\mathrm{CuK}_{\alpha}$ 線を照射し，透過法で測定した。空気散乱を除去 した X 線回折プロファイルについて，X線回折解析ソフ トMDI/JADE5.0 を使用してプロファイルフィッティング によるピーク分離法でピークを分離し, 各ピークの積分 強度の合計から (1) 式を用いて結晶化度 $\left(\mathrm{X}_{\mathrm{c}}\right)$ を算出した。 なお, ここでは半価幅が $9 \mathrm{deg}$ 以下のものを結晶質の散乱, 9deg 以上のものを非晶質の散乱とみなした.

$$
\mathrm{X}_{\mathrm{c}}=\mathrm{I}_{\mathrm{c}} /\left(\mathrm{I}_{\mathrm{c}}+\mathrm{I}_{\mathrm{a}}\right)
$$

$\mathrm{I}_{\mathrm{c}}$ : 結晶性散乱強度, $\mathrm{I}_{\mathrm{a}}$ : 非晶性散乱強度

密度 : キシレンおよび四塩化炭素を用いて密度勾配管 法で測定した.

吸湿性 : 水酸化ナトリウム, 塩化亜鉛, 酢酸カリウム,
塩化カルシウム 2 水塩, 硝酸亜鉛 6 水和物, 硫酸水素ナ トリウム 1 水和物, 酢酸マグネシウム 4 水和物, 塩化ナ トリウム, 塩化アンモニウムおよび塩化カリウムの各種 無機塩飽和水溶液を用いて, 約 $400 \mathrm{mg}$ の試料を各湿度条 件下, $20^{\circ} \mathrm{C}$ で調湿した後, 重量を $10^{-5} \mathrm{gf}$ の精度で精秤し, 水分率を測定した(デシケータ法, 測定数 3 回).

\section{3. 結果と考察}

\section{1 サクシニル化還元羊毛}

表 1 に本実験で用いた試料の略号を, それらの処理条 件や分析結果とともに示す. 羊毛の無水コハク酸に対す るアクセシビリティーを向上させるために羊毛を2-メル カプトエタノール水溶液で還元してからサクシニル化処 理を行った $[3]$. 表 1 に示すように, 本実験条件ではケラ チン中の一部のシスチン残基が還元され, 約 $500 \mu \mathrm{mole} / \mathrm{g}$ のシステイン残基が生じた.また，この還元羊毛をサク シニル化し， $1287 \mu \mathrm{mole} / \mathrm{g} ・$ wool の無水コハク酸（付加率 11.4\%）が付加した. サクシニル化は pH8.0 のリン酸緩衝 溶液中で過剰の無水コハク酸を加えて行うが, 未反応の 無水コハク酸はコハク酸となり反応系の $\mathrm{pH}$ は低下寸る. そこでこの方法では系をアルカリ性に保つために $\mathrm{NaOH}$ を使った $[8]$. この表 1 に示すように, サクシニル化試料 (SCRW) は Na 含有量が高い. このことからサクシニル化 により導入されたカルボキシル基および酸性アミノ酸残 基のカルボキシル基の一部は主として $\mathrm{Na}$ と金属塩 $\left(\mathrm{COO}^{-}\right.$ $\mathrm{Na}^{+}$) を形成していると考えられる. 一般に羊毛中の酸性 アミノ酸残基 $(\mathrm{Glu}+\mathrm{Asp})$ 量は約 $1600 \mu \mathrm{mole} / \mathrm{g}$ であることか ら [9], サクシニル化羊毛中の約 $1 / 3$ のカルボキシル基が カルボキシルイオンとなり, 金属塩を形成していること になる.このような塩の形成による吸湿挙動への影響を 検討するために, サクシニル化還元羊毛を脱塩処理し (DSCRW, D'SCRW), その吸湿挙動を未脱塩処理試料 (SCRW) と比較した. 表 1 の $\mathrm{Na}$ および $\mathrm{K}$ の含有量から, D'SCRW は大部分が脱塩され, また DSCRW は完全に脱 塩されており, これらの試料中の- $\mathrm{COO}^{-} \mathrm{M}^{+}$は- $\mathrm{COOH}$ に変 化したことがわかる.

\section{2 吸湿性}

表 1 に示すように今回用いた試料では結晶化度は還元 によって変化しないが, 還元後サクシニル化することに より低下した。 また, 脱塩処理後も結晶化度はほとんど 変化しなかった. 図 2 および 3 で未処理 $(\mathbf{W})$, 還元処理 羊毛 $(\mathbf{R W})$, 脱塩処理した DSCRW, D'SCRW および脱塩 していない SCRW の $20^{\circ} \mathrm{C}$ での収着等温曲線を比較する. 羊毛の吸脱湿におけるヒステリシス現象はJeffries および 牛腸と中島によって報告されているが $[10,11]$, 本研究の すべての処理羊毛でも平衡吸湿量より平衡脱湿量のほう が大きく, ヒステリシス現象が観察された。しかし SCRW は他の試料羊毛に比べて平衡吸湿量と平衡脱湿量との差 が小さかった。 
Table 1 Abbreviations and analytical data of chemically modified wool fibers in this work.

\begin{tabular}{|c|c|c|c|c|c|c|}
\hline \multirow[t]{2}{*}{ Abbreviation } & \multirow[t]{2}{*}{ Chemical modification } & \multirow{2}{*}{$\begin{array}{l}\text { Add-on }(\mu \mathrm{mole} / \mathrm{g}) \\
\text { of succinic } \\
\text { anhydride }\end{array}$} & \multirow{2}{*}{$\begin{array}{r}\text { Contents } \\
\text { SH group } \\
\end{array}$} & \multicolumn{2}{|c|}{$(\mu$ mole $/ g)$} & \multirow[t]{2}{*}{ Crystallinity $(\%)$} \\
\hline & & & & $\mathrm{Na}$ & $\mathrm{K}$ & \\
\hline $\mathrm{W}$ & Intact & 0 & 8 & 8 & 10 & 40 \\
\hline RW & Reduced & - & 503 & - & - & 40 \\
\hline SCRW & Reduced and succinylated & 1287 & $-* 1)$ & 848 & 6 & 30 \\
\hline D'SCRW & $\begin{array}{l}\text { Reduced, succinylated } \\
\text { and partially desalted }\end{array}$ & 1287 & $-* 1)$ & 78 & 4 & - \\
\hline DSCRW & $\begin{array}{l}\text { Reduced, succinylated } \\
\text { and desalted }\end{array}$ & 1287 & $-* 1)$ & 0 & 0 & 29 \\
\hline
\end{tabular}

${ }^{* 1)}$ A part of SCRW was partially or completely desalted.

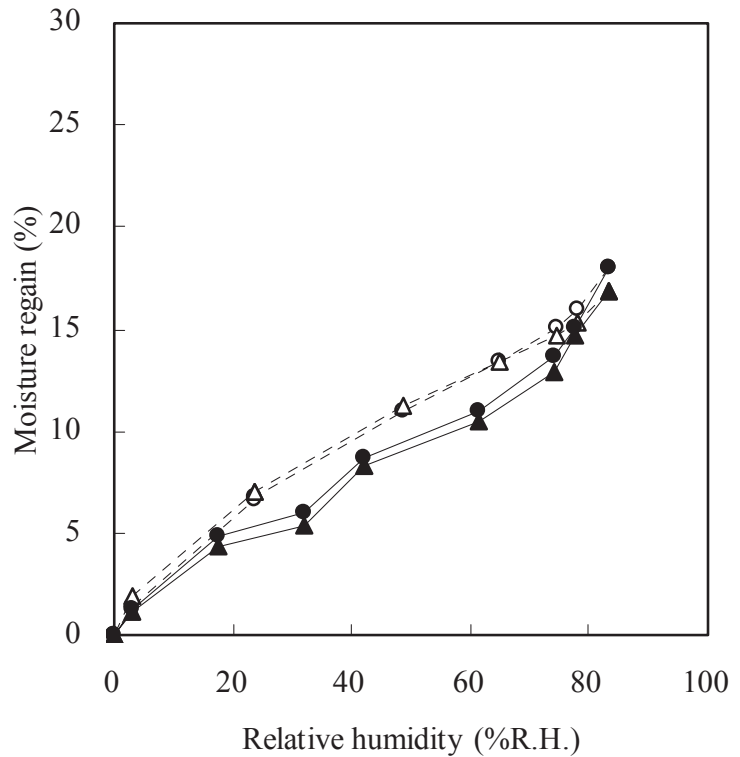

Fig. 2 Sorption isotherms of intact and reduced wool fibers at $20^{\circ} \mathrm{C}$. Adsorption curve : RW. Desorption curve : $(\bigcirc) \mathrm{W} ;(\triangle) \mathrm{RW}$.

図 2 でみられるように，還元処理は吸湿性にほとんど 影響を及ぼしていない。しかし, サクシニル化すると吸 湿性は向上し，特に約 $70 \%$ R.H.以上の高湿度条件下での SCRW の水分率は高く, $83 \%$ R.H.では $25 \%$ を越えていた (図 3). 一方，脱塩した DSCRW およびD'SCRW の吸湿 性は未処理羊毛よりわずかに低かった。これらのことか らカルボキシルイオンは吸湿に大きく寄与していること がわかる。

サクシニル化は無水コハク酸が活性水素を有するアミ ノ酸残基の側鎖に親電子付加寸る反応である. その反応 サイトとしてアミノ基，水酸基およびチオール基が報告 されているが，中でもアミノ基と水酸基は極性が強いた め反応性は高い[4]. このことから羊毛のサクシニル化で は主にこれらの基が反応サイトとなっていることが推測 される．従ってサクシニル化した試料では，アミノ基や 水酸基が減少し, その減少量と当量のカルボキシル基

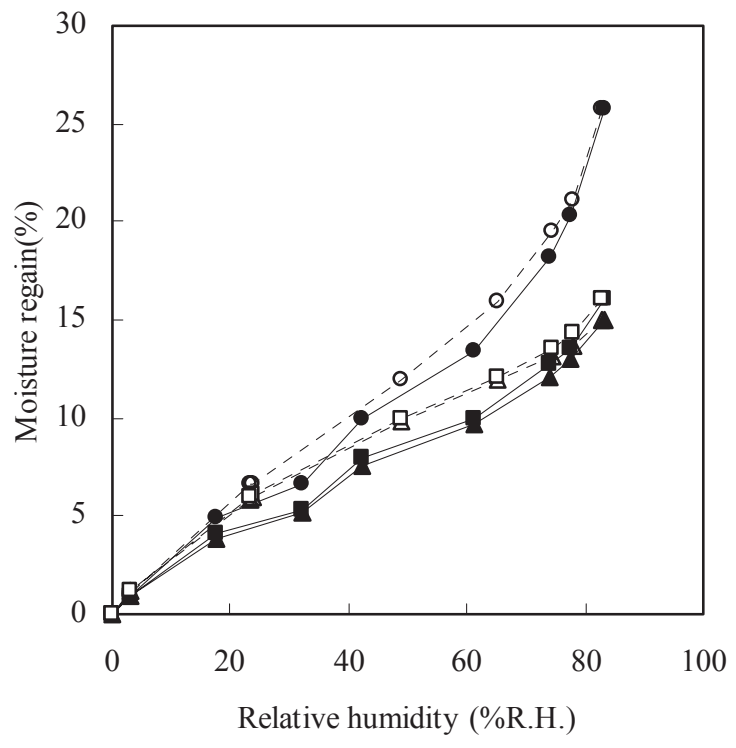

Fig. 3 Sorption isotherms of succinylated wool fibers at $20^{\circ} \mathrm{C}$. Adsorption curve : (O) SCRW ; D'SCRW; (ם) DSCRW. Desorption curve : (O) SCRW ; $\triangle$ ) D'SCRW ; ( $\square)$ DSCRW.

(DSCRW およびD'SCRW)あるいはカルボキシレート (SCRW) が導入されることになる. 先述のように, DSCRW および D'SCRW の吸湿性が未処理羊毛よりやや低い(図 2 および 3)ことから, 羊毛中に本来存在するアミノ基や水 酸基の吸湿への寄与はサクシニル化によって導入された カルボキシル基よりやや大きいことが推測される. 合成 高分子であるがアクリル酸グラフト PET 中のカルボキシ ル基の塩形成による吸湿性への効果は大口ら[12]によっ て確認されており, 今回のカルボキシルイオン導入の効 果についてもこれに対応した結果となった.

DSCRW と SCRW の結晶化度はほぼ等しいが, DSCRW の吸湿性はSCRWより明らかに低い(表 1)。他方，W の 結晶化度はこれらのサクシニル化羊毛より約 $10 \%$ 高いが， 吸湿性はDSCRW に近い。このように, サクシニル化に よる化学変化は結晶化度の变化より吸湿性に強く影響を 及ぼしている。 


\section{3 BET 理論の適用}

これまで羊毛の吸湿挙動には BET 理論や Flory-Huggins $(\mathrm{FH})$ 理論への適用が試みられてきた $[11,13,14]$ 。 また合成 高分子の場合であるが，牛腸らは高分子中の化学環境の 異なる水酸基の水の収着への寄与について BET 理論を応 用して評価した[15]. 本研究ではまずサクシニル化の吸 湿挙動への影響を検討するために，(2)式の BET 理論[16] を適用した. BET モデルは Langmuir の単分子層モデルの 取り扱いを多分子層に拡張したもので，図 2,3 に示される 逆 $\mathrm{S}$ 字型の収着等温線を示す場合に適用されるからであ る.

$$
\mathrm{x} / \mathrm{N}(1-\mathrm{x})=\left(1 / \mathrm{N}_{\mathrm{m}}\right) \cdot \mathrm{C}+(\mathrm{C}-1) \cdot \mathrm{x} / \mathrm{N}_{\mathrm{m}} \cdot \mathrm{C}
$$

$\mathrm{N}$ : 試料 $1 \mathrm{~g}$ 当りに収着された水の量 $(\mathrm{g} / \mathrm{g}), \mathrm{x}$ : 相対圧, $\mathrm{N}_{\mathrm{m}}$ : 単分子層収着量 $(\mathrm{g} / \mathrm{g}), \mathrm{C}$ : 収着エネルギーに関する定数

本実験で扱った羊毛試料への収着が BET 理論に則して いるならば, (2)式から, $\mathrm{x} / \mathrm{N}(1-\mathrm{x})$ と $\mathrm{x}$ は $(\mathrm{C}-1) / \mathrm{N}_{\mathrm{m}} ・ \mathrm{C}$ の 傾きと $\left(1 / \mathrm{N}_{\mathrm{m}}\right) \cdot \mathrm{C}$ の切片をもつ直線関係をもつはずであ る. そこで, 各試料について $\mathrm{x} / \mathrm{N}(1-\mathrm{x})$ を $\mathrm{x}$ に対してプロッ トすると (図 4,5), 各試料とも概して 0.4 以下の低相対圧 領域ではほぼよい直線性を示し, 相対圧が高くなると上 方へのずれが大きくなった。このことから低相対圧下で は, 水分子は緎維中のアミノ酸残基側鎖の極性基に局在 的に収着すると考えられる。そこでBET 理論にそってい る低相対圧領域での収着における単分子層収着量 $\mathrm{N}_{\mathrm{m}}$ を図 4 および 5 の BET プロットから求めた(表 2). SCRW 以 外の $\mathrm{N}_{\mathrm{m}}$ 間には大きな差はないが， SCRW では明らかに増 加しており, 強い収着座席が増加していることを示唆し ている。また, 各試料の非晶領域での収着性を比較する ために, 非晶領域における単分子層収着量 $\left\{\mathrm{N}_{\mathrm{m}} /(1\right.$-結晶化 度/100)\}を $\mathrm{N}_{\mathrm{m}}{ }^{*}$ として求め, $\mathrm{N}_{\mathrm{m}}$ とともに表 2 に示した。 脱塩したサクシニル化還元羊毛の $\mathrm{N}_{\mathrm{m}}^{*}$ は小さいが, 脱塩し ていないSCRW は試料中最も大きく, 図 2 および 3 に示 した吸湿等温曲線の結果によく対応している.

$\mathrm{N}_{\mathrm{m}}$ と同様に BET プロットから収着エネルギーに関する 定数である $\mathrm{C}$ を求め, 式(3)から水の第一層の収着熱 $\mathrm{E}_{1}$ を算出した(表 2).

$$
\mathrm{C}=\mathrm{e}^{\left(\mathrm{E}_{1}-\mathrm{E}_{\mathrm{L}}\right) \mathrm{RT}}
$$

$\mathrm{E}_{1}$ : 第 1 層の収着熱 $(\mathrm{J} / \mathrm{mol}), \mathrm{E}_{\mathrm{L}}$ : 水の液化熱 $(44.099 \times$ $\left.10^{3} \mathrm{~J} / \mathrm{mol}\right), \mathrm{R}$ : 気体定数 $(8.314 \mathrm{~J} / \mathrm{K} \cdot \mathrm{mol}), \mathrm{T}: 293^{\circ} \mathrm{K}$

未処理羊毛と還元羊毛の $\mathrm{C}$ は高く, サクシニル化した 試料では一様にそれらより低く, SCRW のC はもっとも 低い. また， $\mathrm{E}_{1}$ は水分子と高分子基質の結合力を示して いる. 試料間での $\mathrm{E}_{1}$ の差は小さいが，未処理および還元 羊毛に比べて, サクシニル化還元羊毛の $\mathrm{E}_{1}$ のほうがわず かに小さく, カルボキシルイオンを多く含む処理羊毛ほ ど小さい傾向が認められる，吸湿性が高く $\mathrm{N}_{\mathrm{m}}$ が大きいに
Table 2 BET parameters for moisture sorption of the different chemically modified wool fibers.

\begin{tabular}{lcccc}
\hline Sample & $\mathrm{C}$ & $\mathrm{N}_{\mathrm{m}} \times 10^{-2}$ & $\mathrm{~N}_{\mathrm{m}}{ }^{*} \times 10^{-2}$ & $\begin{array}{c}\mathrm{E}_{1} \\
(\mathrm{~kJ} / \mathrm{mol})\end{array}$ \\
\hline W & 10.18 & 5.4 & 9.0 & 49.8 \\
RW & 7.99 & 5.2 & 8.7 & 49.2 \\
& & & & \\
SCRW & 6.29 & 6.6 & 9.4 & 48.6 \\
D'SCRW & 6.77 & 5.0 & $7.0^{* 11}$ & 48.8 \\
DSCRW & 7.64 & 5.1 & 7.3 & 49.1 \\
& & & &
\end{tabular}

\footnotetext{
${ }^{* 1)}$ The value was estimated on the assumption that the crystallinity is $29 \%$.
}

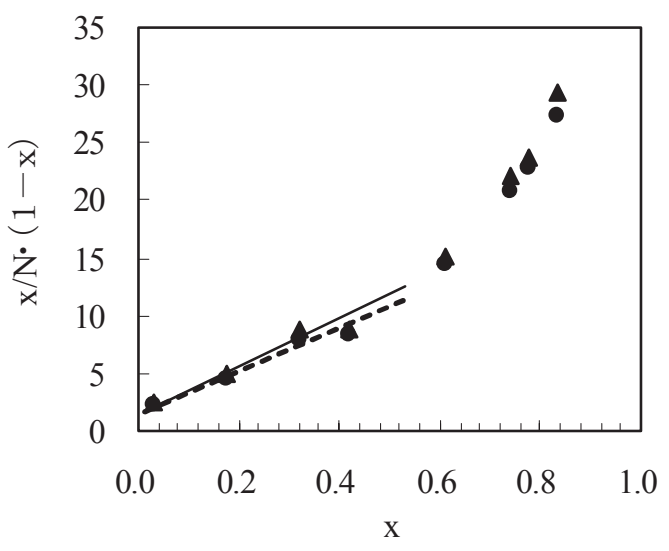

Fig. 4 BET plots of moisture sorption for intact and reduced wool fibers. $(\mathbf{O}) \mathrm{W} ;(\boldsymbol{\Delta}) \mathrm{RW}$.

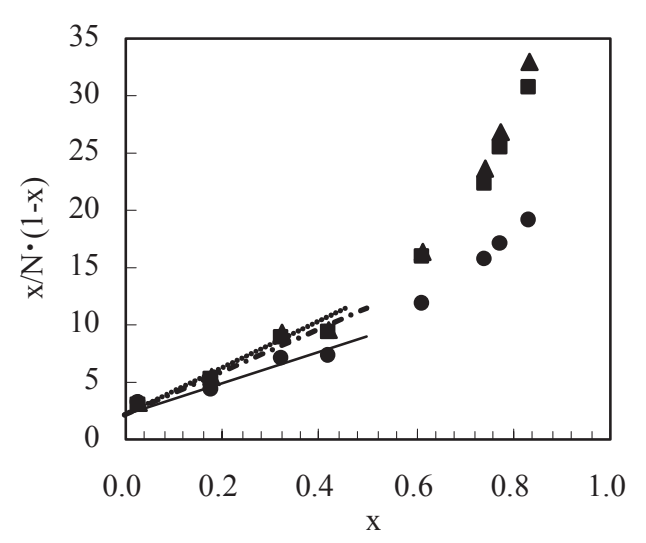

Fig. 5 BET plots of moisture sorption for reduced and succinylated wool fibers. (O) SCRW ; D'SCRW ; ( $\boldsymbol{\square})$ DSCRW. 
もかかわらず， Cおよび $\mathrm{E}_{1}$ が低いという矛盾した結果が 得られた理由として, サクシニル化試料では BET 型の機 構にそって収着する水分子が未処理羊毛等に比べて少な いことが考えられる。

\section{4 BET 理論と高分子溶液論との組み合わせ機構}

各試料の BET プロットが高い相対圧域で直線から上方 にずれたことから，水分子ははじめ極性基に局在的に収 着し(BET 型), その後高分子に無秩序に混合していく, Flory-Huggins (FH)の式 (4) で表される高分子溶液論型の機 構(溶解型)にそっていることが予想された. そこで, BET 型で単分子層が収着した後, 溶解型の機構[17]にそって 収着すると仮定し，(4)式を適用することを試みた。

$$
\ln x=\ln v_{1}+\left(1-v_{1}\right)+\chi_{1}\left(1-v_{1}\right)^{2}
$$

$\mathrm{x}$ : 水 (気体)の相対圧, $v_{1}$ : 水の体積分率, $\chi_{1}$ : 相互作用パ ラメータ

実験值すなわち測定した各相対圧での水の収着量から， 先に求めた $\mathrm{N}_{\mathrm{m}}$ を減じた值を溶解型の機構で収着した水分 量として吸湿試料中の水の体積分率を求め, これを(4) 式 の $v_{1}$ に代入して各相対圧での $\chi_{1}$ を算出した. 実験值から そのまま求めた $\chi_{1}$ は相対圧值によって分散していたが, このように $\mathrm{N}_{\mathrm{m}}$ を差し引いて求めた $\chi_{1}$ は, $\mathrm{W} と \mathrm{RW}$ の場 合のみ一定の範囲に収まった(図 $6 \mathrm{~W}, \mathrm{RW})$.このことか ら単分子層形成後の水蒸気の収着には FH 式の適用が妥当 であると考えられる. 得られた $\chi_{1}$ の平均值を(4)式の $\chi_{1}$ に代入して算出した各相対圧での水の収着量 $(\mathrm{g} / 100 \mathrm{~g})$ を 使って再び収着等温曲線を作成し, 実験值と比較した(図 7). W と RWについては, 相対圧 0.2 以上で実験值と計 算值はよく一致していた (図 7).このことは, 吸湿初期で は水分子はBET 型の機構で収着し, 分子表面に水の単分 子層が形成された後は溶解型の機構でランダムに高分子 基質に混合していくという先に仮定した機構を支持して いる. 他方, 同様の方法で求めたサクシニル化試料の $\chi_{1}$ にはなお若干のばらつきが見られた。図 7 の DSCRW お よびD'SCRW については低〜中相対圧領域で, SCRW に ついてはほぼ全域で実測值による収着等温曲線と計算值 によるものとの間にずれが認められた。サクシニル化試 料では $\mathrm{C}$ および $\mathrm{E}_{1}$ 值からも推測されたように, BET 型の 機構で収着する水分子が少ない, 寸なわち一定量の水分 子は極性基に収着するが，単分子層を完全に形成する前 に溶解型の機構で収着することが予想される. そこで $\mathrm{N}_{\mathrm{m}}$ にファクターをかけた值を, 測定した水の収着量から差 し引いた值を溶解型の機構で収着した水分量として (4) 式 の $v_{1}$ に代入して $\chi_{1}$ を求め, 先と同様に収着等温曲線を作 成した. ファクターの值は, 計算值が実測值にもっとも 近くなるようにトライアンドェラーで求めた. この結果, 図 7 に示すように SCRW では0.3, DSCRWおよび D'SCRW では 0.5 を各 $\mathrm{N}_{\mathrm{m}}$ に乗じると実測值にもっとも近
い収着等温曲線が得られた。このことは, SCRW はBET 型の機構で収着する水分子は単分子層の形成に必要な量 の約 3 割, DSCRW および D'SCRW では約 5 割でありそ れ以上は溶解型の機構で収着したことを示唆する.これ らの結果は, 羊毛に本来存在する水酸基やアミノ基が減 少し, カルボキシルイオンあるいはカルボキシル基が著 しく増加すると水分子の収着機構も変化することを示唆 している.また, SCRW とDSCRW およびD'SCRW での ファクターの差は, カルボキシルイオンとカルボキシル 基の水分子との結合力の差に対応するものと考えられる.

(4) 式の相互作用パラメータは水の高分子への混合の難 易度を示す係数で, 值が小さいほど溶液形成のエネルギー が少ない，才なわち親水性が高くなることを意味する. 先述のように試料に一定量の水分子が極性基に収着した 後溶解型の機構で収着したと推測した水分量を(4) 式に代 入して算出した $\chi_{1}$ を図 8 で比較すると, SCRW 以外の試 料の $\chi_{1}$ は $1.0 \sim 1.5$ の範囲にあり試料間での差はほとんど ない. 他方, SCRWの $\chi_{1}$ は 0.5〜1.0で明らかに低く, 実 験で認められた吸湿性の結果にほぼ対応している.

\section{4. 総 括}

羊毛の吸湿性は本来高いが, サクシニル化によってさ らに大きく向上する.これにはサクシニル化によって導 入された, 金属塩を形成しているカルボキシルイオンの 寄与が大きい. 他方, 脱塩処理によってカルボキシルイ オンがカルボキシル基に変化した脱塩サクシニル化還元 羊毛の吸湿性は未処理羊毛よりわずかに低かった。この ことは, サクシニル化の主要反応サイトである水酸基や アミノ基のほうが, 導入されたカルボキシル基より吸湿 への寄与が大きいことを示唆している.未処理および還

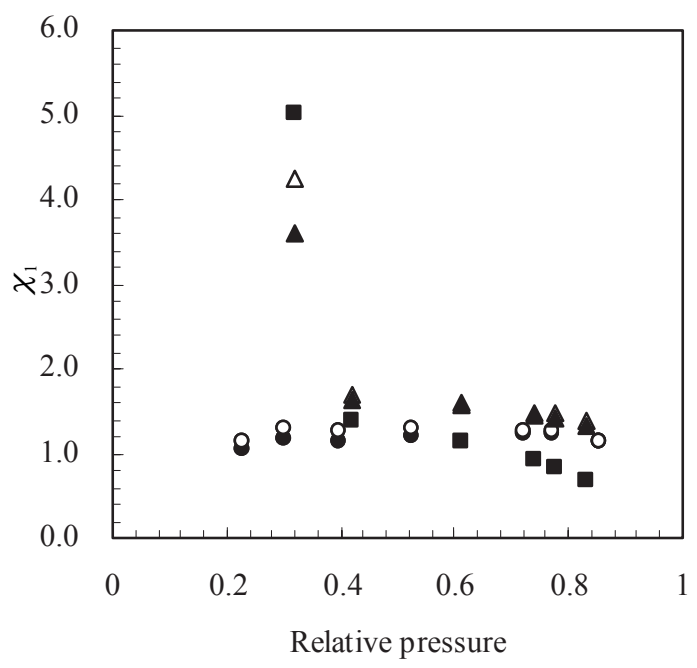

Fig. $6 \chi_{1}$ values of the chemically modified wool fibers. The $\chi_{1}$ values were calculated using dissolution water content obtained by sutracting $\mathrm{N}_{\mathrm{m}}$ from sorbed water. (O) W ; $(\mathrm{O}) \mathrm{RW}$; SCRW ; $(\triangle)$ D'SCRW ; $(\boldsymbol{\Delta})$ DSCRW. 

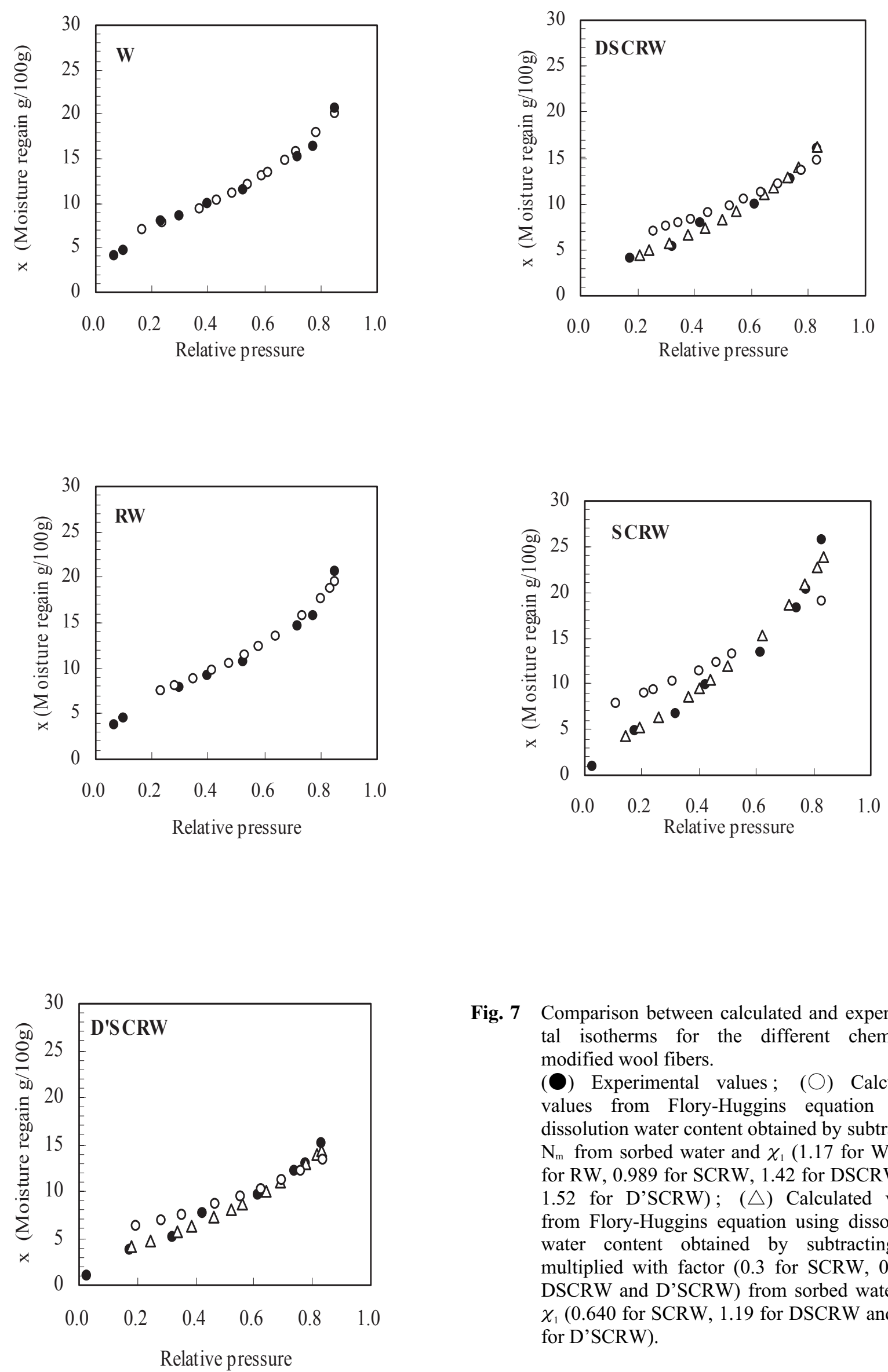

Fig. 7 Comparison between calculated and experimental isotherms for the different chemically modified wool fibers.

(O) Experimental values; ( $\bigcirc)$ Calculated values from Flory-Huggins equation using dissolution water content obtained by subtracting $\mathrm{N}_{\mathrm{m}}$ from sorbed water and $\chi_{1}(1.17$ for $\mathrm{W}, 1.24$ for RW, 0.989 for SCRW, 1.42 for DSCRW and 1.52 for D'SCRW); $(\triangle)$ Calculated values from Flory-Huggins equation using dissolution water content obtained by subtracting $\mathrm{N}_{\mathrm{m}}$ multiplied with factor ( 0.3 for SCRW, 0.5 for DSCRW and D'SCRW) from sorbed water and $\chi_{1}(0.640$ for SCRW, 1.19 for DSCRW and 1.27 for D'SCRW). 


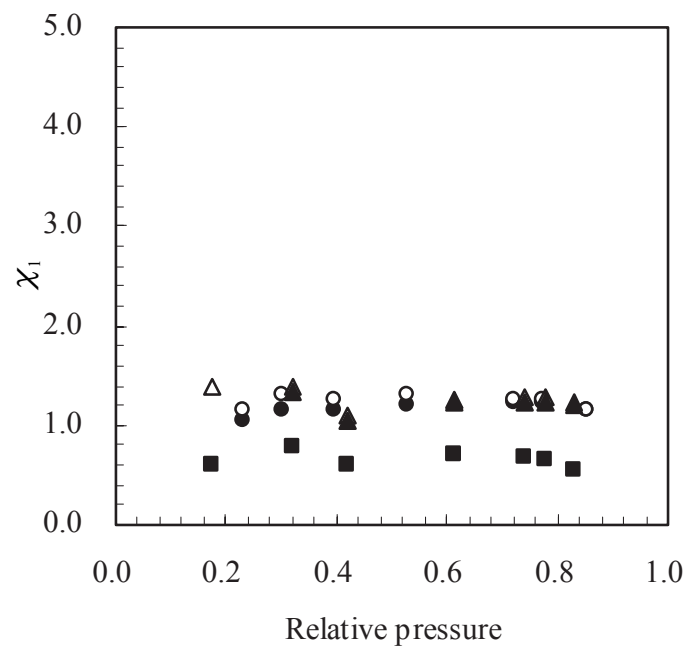

Fig. $8 \chi_{1}$ values of the chemically modified wool fibers. The $\chi_{1}$ values were calculated using dissolution water content obtained by sutracting $\mathrm{N}_{\mathrm{m}}$ multiplied with factor $(0.3$ for SCRW, 0.5 for DSCRW and D'SCRW) from sorbed water. (O) $\mathrm{W} ;(\bigcirc) \mathrm{RW} ;(\mathbf{\square}) \mathrm{SCRW} ;(\triangle)$ D'SCRW ; (A) DSCRW.

元羊毛への吸湿機構として，はじめに水分子は試料の極 性基に局在的に収着し単分子層を形成した後，高分子内 に無秩序に混合していくことが推測された。他方, サク シニル化還元羊毛の場合，単分子層を形成する量の $30 \%$, 脱塩したサクシニル化還元羊毛の場合同じく $50 \%$ の水分 子が収着するとそれ以降は無秩序に混合する機構で収着 することが推測された.

\section{謝 辞}

本研究の $X$ 線回折による分析では㑣リガク応用技術セ ンターの佐々木美穂氏に協力いただき感謝申し上げたい 本研究は平成 17 年度科学研究補助金(基盤研究(C)) 17500517 の補助を受けて行われた。

\section{文 献}

1. N. Kohara, C. Takizawa and K. Sasaki, J. Home Economics Japan, 49(1), 41 (1998).

2. N. Kohara and C. Takizawa, Sen'i Gakkaishi, 53(10), 461 (1997).

3. N. Kohara, M. Kanei and T. Nakajima, Text .Res. J., 71 (12), 1095(2001).

4. I. Klotz, M. Enzymology, 11, 576(1967).

5. N. Kohara, M. Kanei and T. Nakajima, Txt. Res. J. 74(10), 856(2004).

6. Y. Nakamura, K. Kosaka, M. Tada, K. Hirota and S. Kunugi, $7^{\text {th }}$ Int. Wool Text. Res. Conf., Tokyo, Society of Fiber Science and Technology, Japan, 171 (1985).

7. E. H. D. Du Toit, , N. J. J. Van Rensburg, and O. A. Swanepoel, , J. S. Afr. Chem. Inst. 18, 52(1965).

8. H. Toyoda, Y. Chonan, T. Imai, A. Matsunaga and A. Kawamura, Hikakukagaku, 183, 153(1972).

9. A. Prisot and J. Derminot, Appl. Polymer Symp., 18, 45 (1971).

10. R. Jeffries, J. Text. Inst., 51, T399(1960).

11. H. Gocho and T. Nakajima, Sen'i Gakkaishi, 50(7), 321 (1994).

12. M. Ooguchi, K. Igeta and T. Yasumura, Sen'i Gakkaishi, 35, T-28(1978).

13. S. Rosenbaum, J. Polym. Sci. Part C, 31, 45(1970).

14. M.Fukuda, M. Ueda, A. Emoto and H. Kawai, Sen'i Gakkaishi, 46(10), 415(1990).

15. H. Gocho, A. Tanioka and T. Nakajima, J. Colloid Interface Sci., 200, 155(1998).

16. S. Brunauer, P. H. Emmet and E. Teller, J. Amer. Chem. Soc., 60, 309(1938).

17. P. J. Flory, "Principles of Polymer Chemistry", Cornell Univ. Press, Ithaca, N. Y., 1953. 